\title{
The Effects of an Air Conditioning System using the Coanda Effect on an Indoor Office Environment
}

\author{
Hitomi Igarashi ${ }^{1, *}$, Takashi Akimoto ${ }^{2}$, Daisuke Hatori ${ }^{3}$, Shun Kato $^{3}$, Hikari Sakakibara ${ }^{2}$, and Madoka Kimura $^{2}$ \\ ${ }^{1}$ Shinryo Corporation, 41, Wadai, Tsukuba, Ibaraki 300-4247, Japan \\ ${ }^{2}$ Shibaura Institute of Technology, 3-7-5, Toyosu, Koto, Tokyo 135-8548, Japan \\ ${ }^{3}$ Mitsubishi Jisho Sekkei Inc. , Marunouti 2-chome Building, 2-5-1, Marunouchi, Chiyoda, Tokyo 100-0005, Japan
}

\begin{abstract}
In this study, we propose a ductless air conditioning system using the Coanda Effect for a medium size office building to achieve a net-zero energy building (ZEB). The indoor temperature environment and air flow characteristics during cooling and heating conditions created by this system were evaluated. In addition, to validate the computational fluid dynamics (CFD) analysis results when the heating system was activated, the results were compared with the measurement results. The investigation indicated that for cooling, a good thermal environment could be established in the residential area; however, local draught continued to be an issue. For heating, it was confirmed that heating of the residential area could be accomplished using floor suction. In addition, it was shown that the accuracy of the CFD analytical results can be improved by adjusting the input conditions to the actual conditions.
\end{abstract}

\section{Introduction}

In the "Strategic Energy Plan" established by the Cabinet of Japan in 2014, constructing net-zero energy buildings (ZEBs) by around 2030 is the stated goal [1]. In addition, since Japan is earthquake-prone, the building height is legally restricted in each region. In a tenant building, it is important on economic grounds to expand the rentable area as much as possible under the height restrictions and to improve the rentable ratio.

A ductless air conditioning system that employs the Coanda effect which satisfies the above two points for the new construction of medium-size office buildings was evaluated. Table 1 shows an architectural overview of such a building used in this study [2][3].

Table 1. Architectural overview

\begin{tabular}{|c|c|}
\hline Location & Tokyo, Japan \\
\hline Site Area & Approximately $600\left[\mathrm{~m}^{2}\right]$ \\
\hline Total Floor Area & Approximately $4,500\left[\mathrm{~m}^{2}\right]$ \\
\hline Principal Use & Office \\
\hline Floor Height & $3.45[\mathrm{~m}]$ \\
\hline Ceiling Height & $2.80[\mathrm{~m}]($ Excluding under Gang Beam) \\
\hline Story & 10 (B1F - 8F) \\
\hline
\end{tabular}

\footnotetext{
* Corresponding author: igarashi.hi@,shinryo.com
}

The Coanda effect is a phenomenon in which fluid adheres to and moves on to a smooth surface. A ductless air conditioning system that relies on the Coanda effect is a system that conveys air without extensive ducting equipment, as air is blown from the wall along the ceiling surface as shown in Fig. 1.

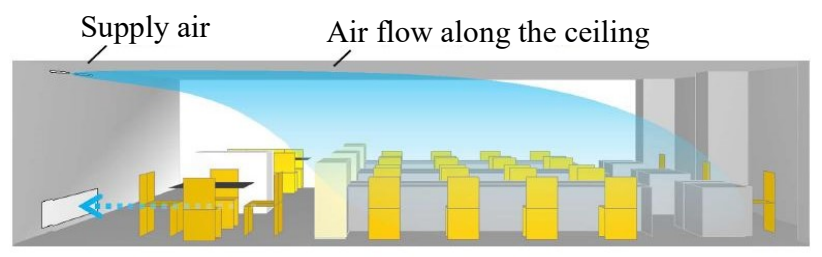

Fig. 1. System Overview.

This method will make duct work in the ceiling unnecessary, therefore reducing the power needed to overcome frictional resistance inside the ducts. This is an advantage since it allows the ceiling height to be lower in new buildings. However, when we use this system for cooling, the air may flows away from the ceiling, draught may occur, and this may create an uncomfortable office environment. When heat is necessary, the supply hot air may stay near the ceiling, and the system may fail to adequately heat the residential area.

Furthermore, when evaluating the pick-up time for heating, it is difficult to reproduce the same heat capacity as actual building in experiments using a test room.

To solve these problems, the room temperature and airflow properties during cooling and heating were evaluated in experiments using the full-scale test room. 
In addition, to validate the computational fluid dynamics (CFD) analysis results when the heating system was activated, the results were compared with the measurement results.

\section{Development of outlet corresponding to the VAV system}

In the air conditioning systems in Japanese office buildings, there are examples that adopt a ductless air conditioning system using the Coanda effect with the constant air volume (CAV) systems. Although adoption of this system improves workability, it is not able to obtain large energy saving as compared with general air conditioning system. On the other hand, in Japan, variable air volume (VAV) systems are quite common to save energy for HVAC (Fig. 2). Table 2 shows the trial calculation conditions of power for conveyance of HVAC. For the calculation, the air conditioning load data of an actual office building (10 minute intervals for 1 year) was used, and the air volume necessary to handle this load using the VAV system was calculated. The pressure loss in the duct was assumed to be proportional to the square of the air flow rate. As a result, compared with the CAV duct air conditioning system, the power required for HVAC could be reduced about $65 \%$ in the VAV ductless air conditioning system.

Table 2. Trial Calculation Conditions of Power for Conveyance of HVAC.

\begin{tabular}{|c|c|}
\hline Air Volume & $\begin{array}{c}\text { Maximum Air Volume } 8,000\left[\mathrm{~m}^{3} / \mathrm{h}\right] \\
\text { ※Variable Air Volume Range } \\
\text { Air Cooling (Apr.-Oct.) }: 40-100[\%] \\
\text { Air Heating (Nov.-Mar.) }: 90-100[\%]\end{array}$ \\
\hline $\begin{array}{c}\text { Fan Total } \\
\text { Efficiency }\end{array}$ & $60[\%]$ \\
\hline $\begin{array}{c}\text { Formula for } \\
\text { Computation }\end{array}$ & $\begin{array}{c}\text { Power for Conveyance of HVAC }[\mathrm{kW}] \\
=\left(\text { Air Volume }\left[\mathrm{m}^{3} / \mathrm{min}\right] \times \text { Total Fan }\right. \\
\text { Pressure }[\text { Pa }]) /(60[\mathrm{~s} / \mathrm{min}] \times 1,000 \times \text { Total } \\
\text { Pressure Efficiency })\end{array}$ \\
\hline
\end{tabular}

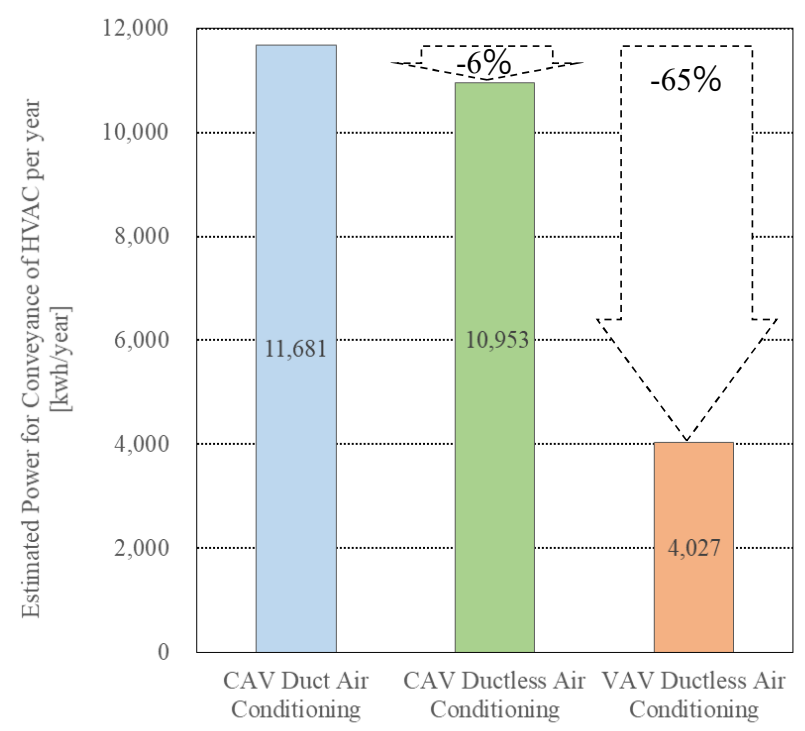

Fig. 2. Power for Conveyance of HVAC per year.
Based on this, we developed technology for a ductless air conditioning system that can variably control the air volume. However, if the air volume is controlled with a general-purpose outlet, it is not possible to generate a sufficient throw by lowering the blowing air velocity when the air flow is low, and it becomes difficult to maintain the indoor temperature (Fig. 3).

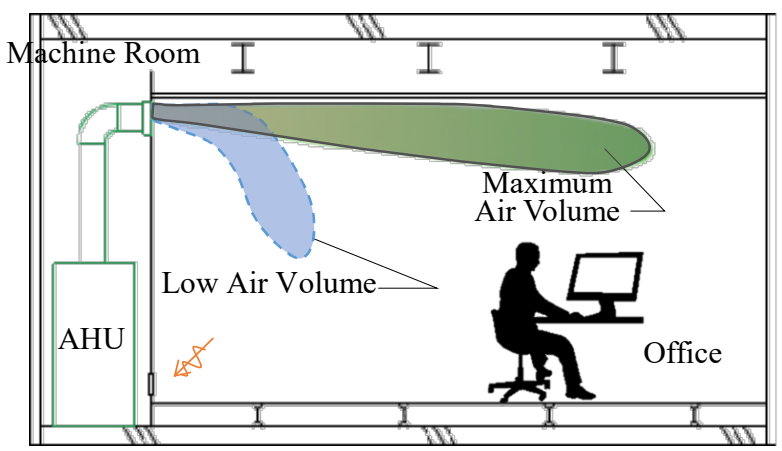

Fig. 3. Changing throw by using the VAV control.

To solve this problem, we developed an "autonomous" outlet, which uses no electric power, as shown in Figs. 4 and 5. By using this outlet, it was possible to supply air at a constant velocity even if the air volume fluctuated. A movable blade with a weight was installed inside the outlet, and the movable blade was moved up and down by the air pressure of the air flow so that the opening area is automatically adjusted according to changes in the air volume. Thus, due to the variable opening area, the air velocity could be constant.

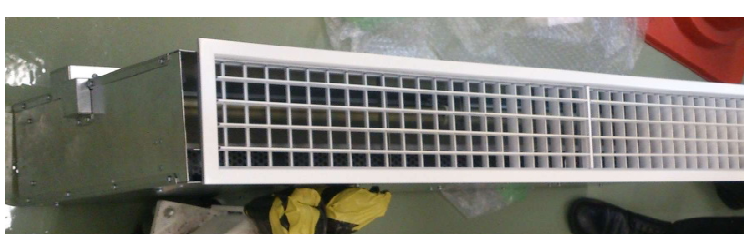

Fig. 4. The autonomous air velocity constant outlet.

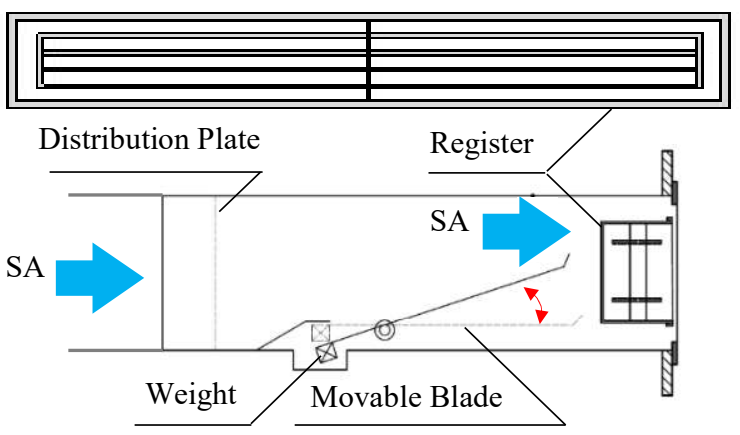

Fig. 5. Overview of the autonomous air velocity constant outlet.

Fig. 6 shows the profiles of outlet air velocity in different air volume. At the maximum air volume of $1,000 \mathrm{~m}^{3} / \mathrm{h}$, it was found that the air velocity was constant even if the air volume was reduced by $70 \%$. 


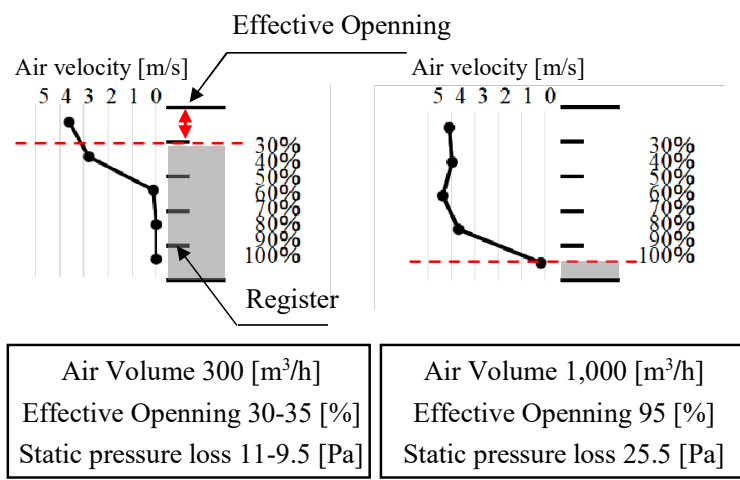

Fig. 6. The profiles of outlet air velocity in different air volume.

\section{Construction of a full-scale test room}

Although high energy savings can be archived in the ductless air conditioning system using the Coanda effect, there is a concern that the indoor environment will be significantly influenced by a decrease in the air volume even if the air velocity is constant. Therefore, we decided to construct a full-scale test room, confirm the behaviour of the airflow in the system, and verify the air conditioning performance. Fig. 7 shows the outline of the full-scale test room, and Table 3 summarises the specifications.

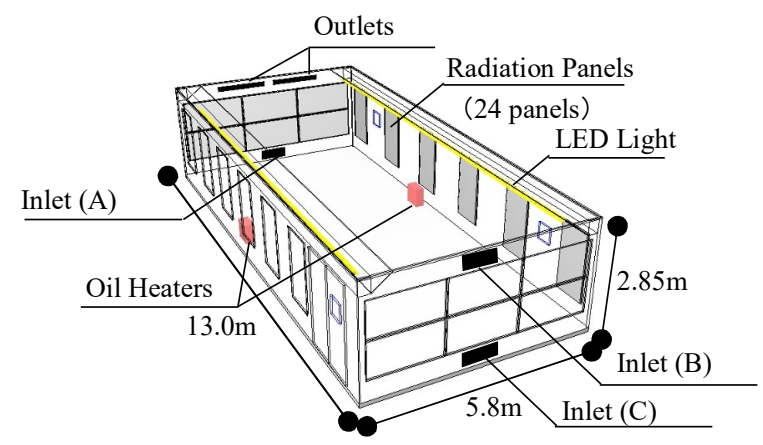

Fig. 7. Outline of the full-scale test room.

Table 3. Specifications of the full-scale test room.

\begin{tabular}{|c|c|}
\hline Dimension & $13.0[\mathrm{~m}] \times 5.80[\mathrm{~m}] \times 2.85[\mathrm{~m}]$ \\
\hline Specific & $42 \mathrm{~mm}$ Insulation Panel \\
\hline $\begin{array}{c}\text { Interior } \\
\text { Decorating }\end{array}$ & $\begin{array}{c}\text { (Floor) Carpet } \\
\text { (Walls, Ceiling) Paint application }\end{array}$ \\
\hline $\begin{array}{c}\text { Simulated } \\
\text { Load }\end{array}$ & $\begin{array}{c}\text { (People / equipment) Oil Heaters } 3.0[\mathrm{~kW}] \\
\text { (Light) LED Light } 0.62[\mathrm{~kW}] \\
\text { (Structure) Radiation Panels }-3.9 \sim 6.2[\mathrm{~kW}]\end{array}$ \\
\hline AHU & $\begin{array}{c}\text { Maximum Air Volume } 3,000\left[\mathrm{~m}^{3} / \mathrm{h}\right] \\
\text { Cooling Capacity } 22[\mathrm{~kW}]\end{array}$ \\
\hline HEX & $\begin{array}{c}\text { Heat Exchange Amount } 5.0[\mathrm{~kW}] \\
\text { Heat-Transfer Area } 0.82\left[\mathrm{~m}^{2}\right]\end{array}$ \\
\hline
\end{tabular}

In this controlled environmental setting, two autonomous air velocity constant outlets were installed, and three switchable inlets were installed to examine the influence of the positions. In addition, to make the skin load, radiation panels were installed on the wall surface, and hot water was supplied for the cooling and cold water was supplied for the heating. Table 4 shows the specifications of the radiation panels.

Table 4. Specification of the radiation panels.

\begin{tabular}{|c|c|}
\hline Surface & Aluminium Sheet \\
\hline $\begin{array}{c}\text { Thermal insulation } \\
\text { material }\end{array}$ & GW-32K 25t \\
\hline Refrigerant & Water \\
\hline $\begin{array}{l}\text { Temperature of } \\
\text { Panel Surface }\end{array}$ & $16.0-40.0\left[{ }^{\circ} \mathrm{C}\right]$ \\
\hline Panel Area & $1.62\left[\mathrm{~m}^{2} / \mathrm{panel}\right]$ \\
\hline Cooling Capacity & $\begin{array}{c}0.099\left[\mathrm{~W} / \mathrm{m}^{2}\right] \\
\text { (Indoor Temperature } 22\left[{ }^{\circ} \mathrm{C}\right] \\
\text { Supply Water Temperature } 8\left[{ }^{\circ} \mathrm{C}\right] \text { ) }\end{array}$ \\
\hline Heating Capacity & $\begin{array}{c}0.159\left[\mathrm{~W} / \mathrm{m}^{2}\right] \\
\text { (Indoor Temperature } 26\left[{ }^{\circ} \mathrm{C}\right], \\
\left.\text { Supply Water Temperature } 45\left[{ }^{\circ} \mathrm{C}\right]\right)\end{array}$ \\
\hline
\end{tabular}

\section{Evaluation of indoor environment during cooling}

When the ductless air conditioning system using the Coanda effect is activated, the air current adhering to the ceiling surface due to the Coanda effect flows away from the ceiling surface at a certain point and descends to the residential area. To determine the exfoliation position of this airflow and the influence of the airflow in the residential area, the indoor air speed and the temperature distribution were measured, respectively.

Table 5 summarises the measurement conditions. The outlets velocity was limited to $3 \mathrm{~m} / \mathrm{s}$ due to the noise created at the outlets. The heat load from peoples and equipments were simulated using two oil heaters. In addition, the heat load from the structure was simulated by heating the radiation panels. 
Table 5. Indoor environment measurement conditions.

\begin{tabular}{|c|c|c|c|}
\hline & Temperature & \multicolumn{2}{|c|}{$26.0\left[{ }^{\circ} \mathrm{C}\right]$} \\
\hline \multicolumn{2}{|c|}{ Temperature } & \multicolumn{2}{|c|}{$16.0\left[{ }^{\circ} \mathrm{C}\right]$} \\
\hline \multicolumn{2}{|c|}{ Outlet Velocity } & \multicolumn{2}{|c|}{$3.0[\mathrm{~m} / \mathrm{s}]$} \\
\hline \multicolumn{2}{|c|}{ Air Volume } & \multicolumn{2}{|c|}{$1,480\left[\mathrm{~m}^{3} / \mathrm{h}\right]$} \\
\hline \multicolumn{2}{|c|}{ Position of Inlet } & \multicolumn{2}{|c|}{ Inlet (A) } \\
\hline \multirow{4}{*}{$\begin{array}{l}\text { Heat } \\
\text { Load }\end{array}$} & People & $1.0[\mathrm{~kW}]$ & \multirow{2}{*}{$\begin{array}{l}\text { Simulated with } \\
\text { oil heaters }\end{array}$} \\
\hline & Equipment & $2.0[\mathrm{~kW}]$ & \\
\hline & Light & $0.62[\mathrm{~kW}]$ & - \\
\hline & Structure & $1.4[\mathrm{~kW}]$ & $\begin{array}{l}\text { Simulated with } \\
\text { radiation panels }\end{array}$ \\
\hline
\end{tabular}

\subsection{Air velocity distribution}

\subsubsection{Measuring methods}

The air velocity distribution in the room was measured at the locations set at $2.0 \mathrm{~m}$ intervals from the outlets, and at $0.25 \mathrm{~m}$ intervals around the area where the air was assumed to flow away from the ceiling, as shown in Fig. 8. We measured two cross-sections, the centre of the room and the centre of the outlet. Air velocity distribution was measured using a three-dimensional ultrasonic anemometer. The air velocity was measured at 1 second intervals and averaged over 60 seconds. After the three-dimensional ultrasonic anemometer moved between measurement points, an interval of 30 seconds or more was provided to ensure the stability of the air flow field.

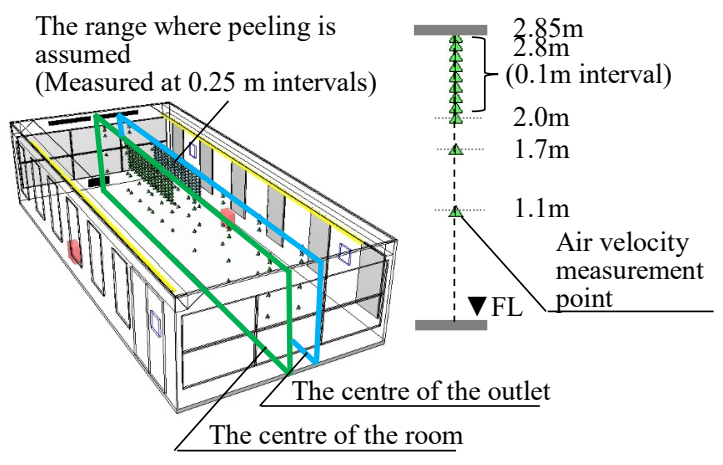

Fig. 8. Air velocity measurement position.

\subsubsection{Measurement results}

Figs. 9 and 10 show the air velocity distribution diagrams for each section. When the distance from the outlet to the position where the air velocity in the vicinity of the ceiling became $0.5 \mathrm{~m} / \mathrm{s}$ or less, this was considered to be the peeling position, and the peeling distance was about $3.5 \mathrm{~m}$ in the centre cross section of the room. The peeled air flow descended, and there was a place where it became $0.5 \mathrm{~m} / \mathrm{s}$ or more within the residential area of F.L. $+1.7 \mathrm{~m}$ or less. On the other hand, the peeling distance of the centre of the outlet was about $3.7 \mathrm{~m}$, which was roughly equivalent to the centre of the room, but the air velocity in the residential area was reduced to $0.5 \mathrm{~m} / \mathrm{s}$ or less, and a draught was not created.

Therefore, it is considered that the air flow coming from the two outlets merged at the centre of the room, and after becoming a single mass, it peeled from the ceiling and descended.

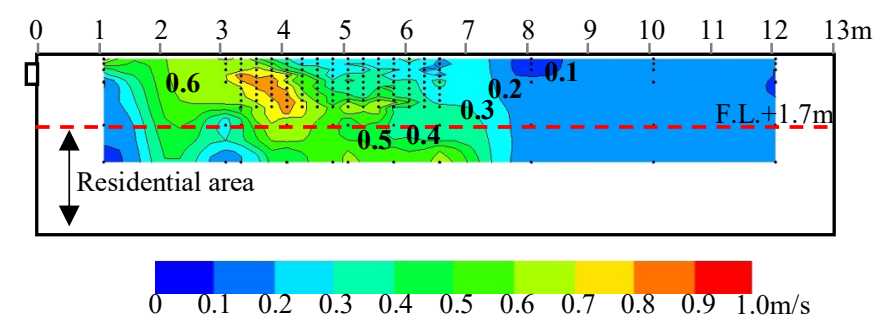

Fig. 9. Air velocity distribution (centre of the room).

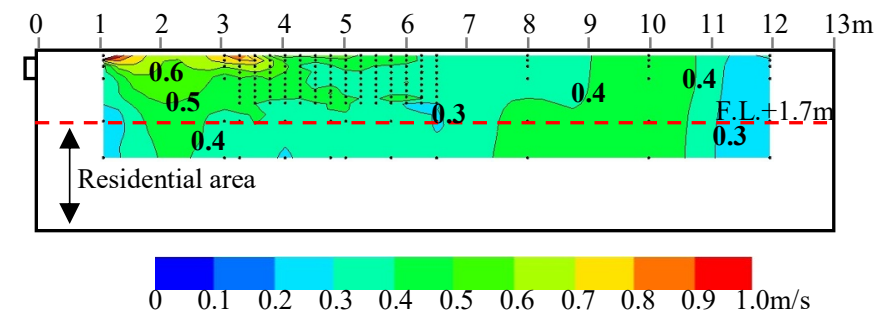

Fig. 10. Air velocity distribution (centre of the outlet).

\subsection{Temperature distribution}

\subsubsection{Measuring methods}

In addition to the measurement conditions in Table 5, temperature distribution measurements were also obtained at a supply air temperature of $20{ }^{\circ} \mathrm{C}$ (air volume $2,470 \mathrm{~m}^{3} / \mathrm{h}$, outlet velocity $3 \mathrm{~m} / \mathrm{s}$ ). In the measurement of temperature, to eliminate the influence of radiation from the radiation panels, measurements were made by covering the thermocouple with tubular aluminium foil. Fig. 11 shows the thermocouple installation position.

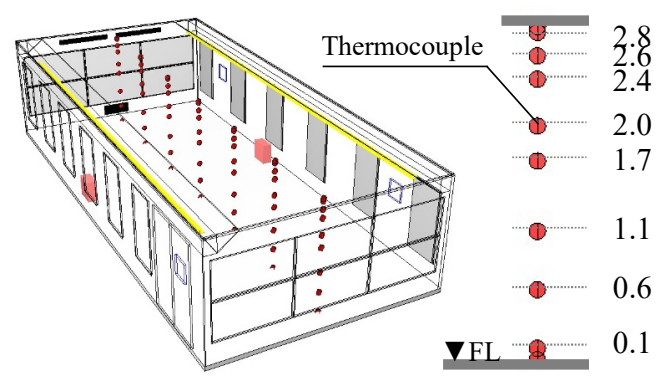

Fig. 11 Thermocouple installation position. 
Measurement intervals were equally spaced $2.0 \mathrm{~m}$ starting from the position located $0.5 \mathrm{~m}$ from the outlet. The temperature was measured at 10 different ports in height, including the surface of the floor and ceiling. The installation positions are suggested by the Architectural Institute of Japan. In ISO-7730, it is recommended that the temperature difference between F.L. $+0.1 \mathrm{~m}$ and F.L. $+1.1 \mathrm{~m}$ should be within $3{ }^{\circ} \mathrm{C}$ [4], and in ASHRAE Standard 55, the temperature difference between F.L. $+0.1 \mathrm{~m}$ and F.L. $+1.7 \mathrm{~m}$ is $3{ }^{\circ} \mathrm{C}$ [5].

\subsubsection{Measurement results}

Fig. 12 and 13 show temperature distribution of the supply air temperatures $16{ }^{\circ} \mathrm{C}$ and $20^{\circ} \mathrm{C}$. The difference between the upper and lower temperature of the residential area (F.L. $+0.1 \mathrm{~m} \sim$ F.L. $+1.7 \mathrm{~m}$ ) was $1.7{ }^{\circ} \mathrm{C}$ at the maximum with the supply air temperature of $16^{\circ} \mathrm{C}$ (6.5 $\mathrm{m}$ from the outlet). In addition, the maximum temperature difference between the upper and lower temperature was $0.8{ }^{\circ} \mathrm{C}$ with the supply air temperature of $20{ }^{\circ} \mathrm{C}$ (4.5 m from the outlet). Furthermore, the maximum temperature difference in the entire residential area was $2.4^{\circ} \mathrm{C}$ when the supply air temperature was $16{ }^{\circ} \mathrm{C}$, which indicated that the temperature environment was comfortable.

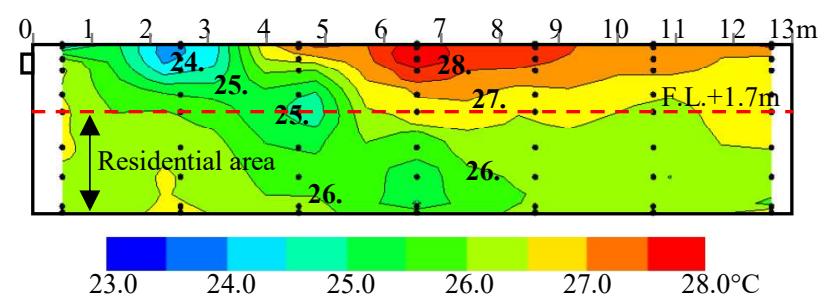

Fig. 12. Temperature distribution (Supply air temperature $\left.16^{\circ} \mathrm{C}\right)$.

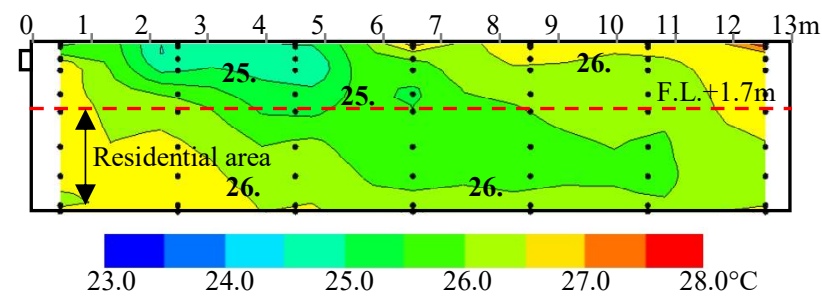

Fig. 13. Temperature distribution (supply air temperature of $\left.20^{\circ} \mathrm{C}\right)$.

\section{Evaluation of indoor environment during heating}

\subsection{Measurement of pick-up time}

In a ductless air conditioning system using the Coanda effect, since the blown airflow moves along the ceiling surface, it is possible that the residential area barely warms during heating. In addition, it is difficult to recreate the same heat capacity as an actual building interior, even in a full-scale test room, and thus, the indoor environment may be different from the real-world conditions with respect to heat pick-up. Therefore, environmental measurements during heating were obtained to better understand the influence of the positions of the inlets for the temperature in the room. Furthermore, to validate the CFD analysis results at the time of heating pick-up, the results and measurement results were compared.

\subsubsection{Measurement methods}

Table 6 summarises the pick-up measurement conditions. The air inlet positions were changed, and measurements were taken when the heating system was activated. At the air inlet positions, the air inlet (B) was used as ceiling suction and air inlet (A) and (C) were used for floor suction (Fig. 7).

Table 6. Pick-up measurement conditions.

\begin{tabular}{|c|c|c|}
\hline Case 1 & Ceiling suction & - \\
\hline Case 2 & Floor suction & (A) : (C) $=50 \%: 50 \%$ \\
\hline
\end{tabular}

Table 7 summarises the pick-up measurement conditions. To align the initial conditions of each case, the door was opened the day before measurements were taken, and the experiments started from the state in which the inside of the room and each elements were equalised with the external temperature. The start of the experiment was set for 9:00 the following morning, and the air conditioner and radiation panels were operated with the door closed. The radiant panels were kept on at all times and continued to provide a constant heating load. The vertical temperature distribution was measured in the centre section of the room.

Table 7. Pick-up measurement summary.

\begin{tabular}{|c|c|}
\hline $\begin{array}{c}\text { Measurement } \\
\text { Date }\end{array}$ & $\begin{array}{c}\text { Case } 12018 / 03 / 06 \\
\text { Case 2 2018/03/02 }\end{array}$ \\
\hline $\begin{array}{c}\text { Measurement } \\
\text { Location }\end{array}$ & Tsukuba, Ibaraki, Japan \\
\hline $\begin{array}{c}\text { Set Room } \\
\text { Temperature }\end{array}$ & $22.0\left[{ }^{\circ} \mathrm{C}\right]$ \\
\hline $\begin{array}{c}\text { Supply Air } \\
\text { Temperature }\end{array}$ & $\begin{array}{c}26.5\left[{ }^{\circ} \mathrm{C}\right]-27.0\left[{ }^{\circ} \mathrm{C}\right] \\
\left(\text { Set Value }: 26.0\left[{ }^{\circ} \mathrm{C}\right]\right)\end{array}$ \\
\hline Air Volume & $\begin{array}{c}2,450\left[\mathrm{~m}^{3} / \mathrm{h}\right]-2,750\left[\mathrm{~m}^{3} / \mathrm{h}\right] \\
\left(\text { Set Value }: 2,700\left[\mathrm{~m}^{3} / \mathrm{h}\right]\right)\end{array}$ \\
\hline Outlet Size & $(\mathrm{W}) 1.46[\mathrm{~m}] \times(\mathrm{H}) 0.095[\mathrm{~m}] \times 2$ outlets \\
\hline Outlet Velocity & $\begin{array}{c}2.5[\mathrm{~m} / \mathrm{s}]-2.8[\mathrm{~m} / \mathrm{s}] \\
(\text { Set Value }: 3.0[\mathrm{~m} / \mathrm{s}])\end{array}$ \\
\hline Heat Load & $\begin{array}{c}1.4[\mathrm{~kW}]-2.1[\mathrm{~kW}] \\
(\text { Set Value }: 2.0[\mathrm{~kW}])\end{array}$ \\
\hline
\end{tabular}




\subsubsection{Measurement results}

Fig. 14 shows the temperature transition in the centre of the room $(4.5 \mathrm{~m}$ position from the outlet, F.L. $+1.1 \mathrm{~m})$. Since the external temperature and the initial temperature of the room were virtually the same in both cases, temperatures were directly compared. Case 1 (ceiling suction) did not reach the set room temperature $22.0{ }^{\circ} \mathrm{C}$ even three hours after start-up. On the other hand, Case 2 (floor suction) started earlier than Case 1, and reached the set room temperature after 1.5 hours had elapsed. In Case 1 and Case 2, a temperature difference of about $2{ }^{\circ} \mathrm{C}$ was constantly generated in the centre of the room at all times, and it was found that Case 2 was more efficient in heating the space.

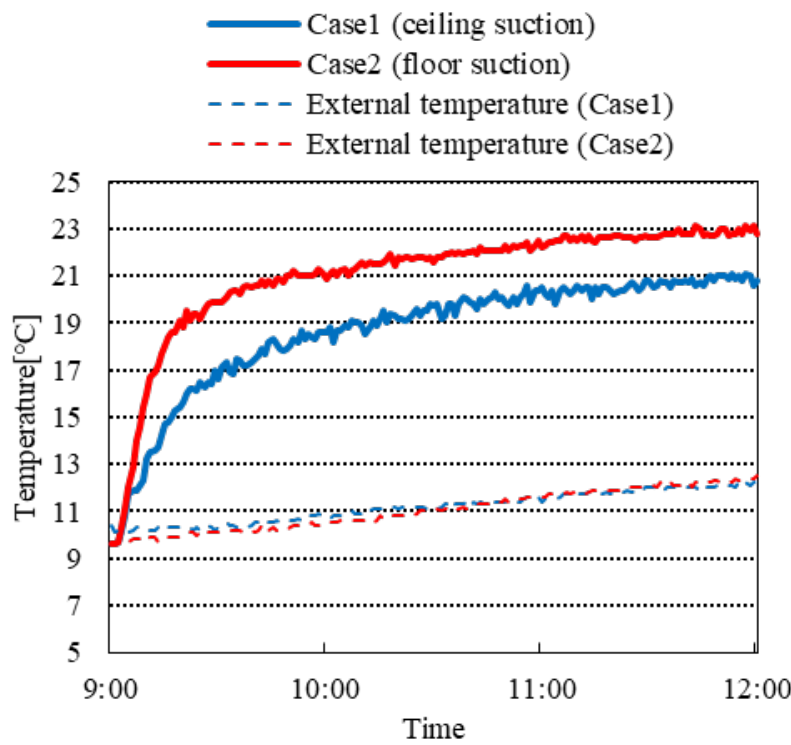

Fig. 14. Temperature transition in the centre of the room (F.L. $+1.1 \mathrm{~m})$

Figs. 15 and 16 show the temperature distributions at 9:00, 10:00 and 11:00. In Case 2 (floor suction), since the air inlets were in a low position of the room, after the blown air current reached the wall on the opposite side, it was able to descend along the wall and heat the vicinity of the floor. On the other hand, in Case 1 (ceiling suction), the warm air near the ceiling was exhausted from the inlet (B), resulting in a large temperature difference between the top and bottom of the room. The temperature at F.L. $+0.1 \mathrm{~m}$ (feet) in the centre of the room $\left(4.5 \mathrm{~m}\right.$ from the outlet) was $17.6^{\circ} \mathrm{C}$ in Case 1 , and $19.6{ }^{\circ} \mathrm{C}$ in Case 2 . In addition, when looking at the difference in vertical temperature between F.L. $+0.1 \mathrm{~m}$ and F.L. $+1.1 \mathrm{~m}$ (head height at the chair position), it was $2.9^{\circ} \mathrm{C}$ for Case 1 and $2.6{ }^{\circ} \mathrm{C}$ for Case 2 .

Therefore, it is considered that floor suction has a smaller vertical temperature difference across the entire room than ceiling suction and can pick up more quickly.

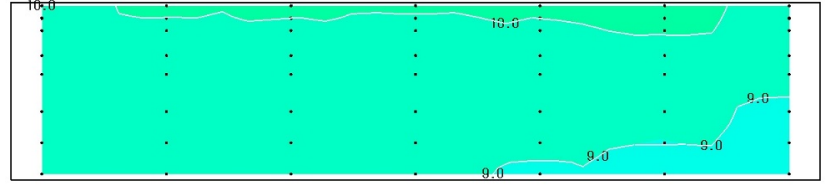

(a) 9:00

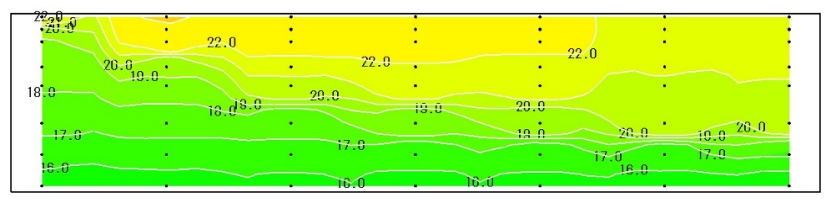

(b) 10:00

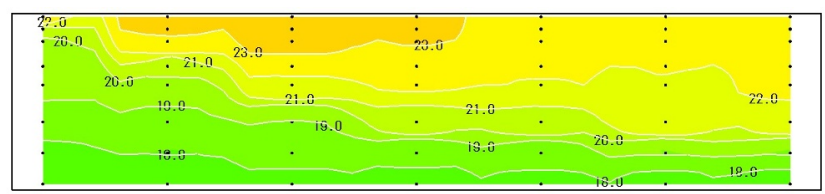

(c) $11: 00$

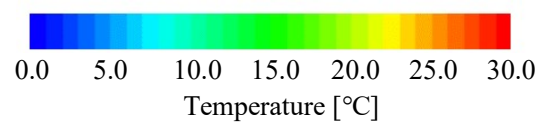

Fig. 15. Temperature distributions (Case 1).

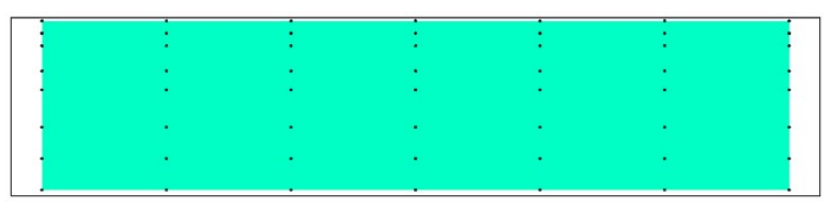

(a) 9:00

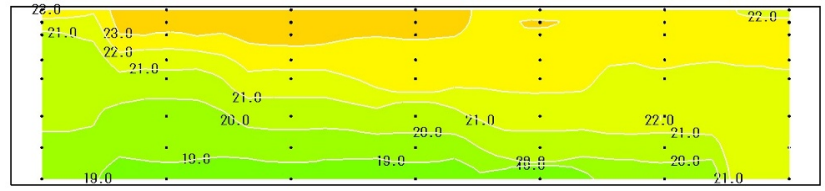

(b) 10:00

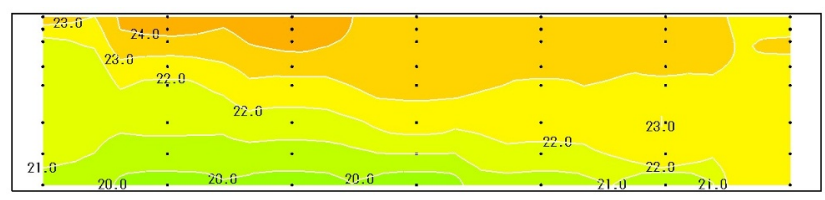

(c) $11: 00$

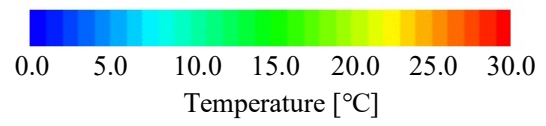

Fig. 16. Temperature distributions (Case 2).

\subsection{Evaluation of consistency of CFD analysis}

As indicated previously, actual measurements were obtained in a full-scale test room, but since the heat capacity and physical property values of the structure are different from actual office buildings, it thought that the pick-up conditions in reality could not be reproduced. 
For this reason, we reproduced the environment of Case 2 (floor suction) using CFD analysis, and validated the results to ascertain whether prediction of pick-up time can be made.

\subsubsection{Analysis outline}

Fig. 17 shows the CFD analysis model.

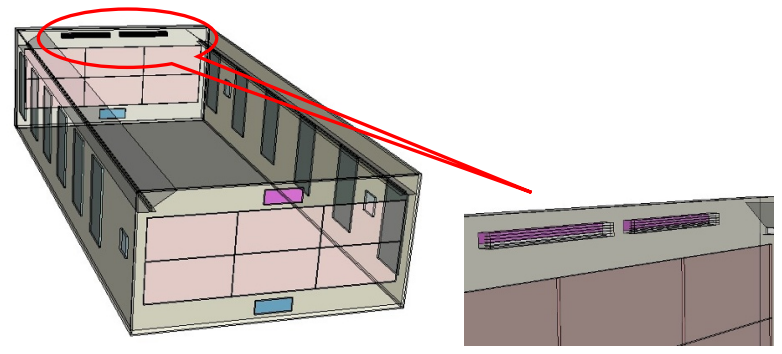

Fig. 17. CFD analysis model.

Table 8 shows the CFD input conditions. To reproduce the pick-up time, transient analysis from 9:00-11:00 was performed. The time interval was $0.004 \mathrm{~s}$ (CourantFriedrichs-Lewy Condition < 1). For the supply air temperature and air volume, the measurement values were used as input, and the heat accumulation of the AHU and the duct were taken into account. The measured heat quantity was set on the radiation panels.

Table 8. CFD input conditions

\begin{tabular}{|c|c|}
\hline Software & $\begin{array}{c}\text { scSTREAM ver.12 } \\
\text { (Software Cradle Co., Ltd.) }\end{array}$ \\
\hline $\begin{array}{l}\text { Analytic } \\
\text { Algorithm }\end{array}$ & SIMPLEC (Transient analysis) \\
\hline $\begin{array}{l}\text { Turbulence } \\
\text { Model }\end{array}$ & $\begin{array}{l}\text { Standard k-epsilon } \\
\text { Model }\end{array}$ \\
\hline $\begin{array}{c}\text { Difference } \\
\text { Scheme of the } \\
\text { Advection Term }\end{array}$ & QUICK second-order accuracy \\
\hline Analysis Legion & $22.9 \times 13.2 \times 2.85[\mathrm{~m}]$ \\
\hline $\begin{array}{c}\text { Initial } \\
\text { Temperature }\end{array}$ & $9.55\left[{ }^{\circ} \mathrm{C}\right]$ \\
\hline Emissivity & 0.9 \\
\hline $\begin{array}{c}\text { Convective Heat } \\
\text { Transfer } \\
\text { Coefficient }\end{array}$ & $\begin{array}{c}\text { (Ceiling, floor, window, radiation panel) } \\
\text { Jürges' equation } 5.6+4.0 v[6] \\
\text { (smooth surface) } \\
v: \text { velocity }[\mathrm{m} / \mathrm{s}] \\
\text { (wall, beam) } 10.0\left[\mathrm{~W} /\left(\mathrm{m}^{2} \cdot \mathrm{K}\right)\right]\end{array}$ \\
\hline $\begin{array}{l}\text { Heat Transfer } \\
\text { Coefficient }\end{array}$ & (outdoor side) $9.3\left[\mathrm{~W} /\left(\mathrm{m}^{2} \cdot \mathrm{K}\right)\right]$ \\
\hline
\end{tabular}

\subsubsection{Analysis results}

Fig. 18 shows the transition of temperature at each measurement points. At all the measurement points, the
CFD analysis results tended to increase more rapidly than the actual measurements, but at 11:00, the temperature converged to a temperature relatively close to that of the experiment. Although measurement error ranges were observed at points (D) and (E), they were not particularly significant. For point (E), the water supply pipe of the radiation panels were not reproduced in CFD analysis, and it is possible that a difference occurred in the disturbance of the air flow and the amount of heat radiation. For point (D), it is thought that the error at point (E) was influenced further by the inability to reproduce the thickness and physical properties of the carpet.

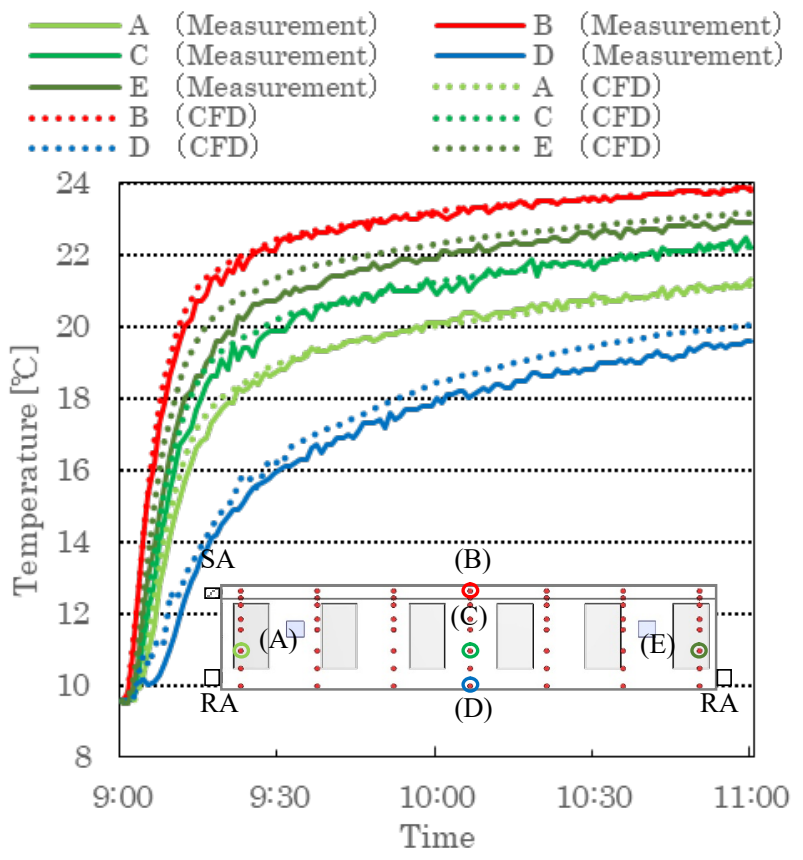

Fig. 18. The transition of temperature at each measurement points.

Fig. 19 shows the temperature distribution at 11:00. Although the temperature of F.L. $+0.1 \mathrm{~m}$ at the centre of the room (at $4.5 \mathrm{~m}$ from the outlet) was $18.7{ }^{\circ} \mathrm{C}$, the vertical temperature difference between F.L. $+0.1 \mathrm{~m}$ and F.L. $+1.1 \mathrm{~m}$ was $2.8^{\circ} \mathrm{C}$, which was roughly in agreement with Fig. 16(c).

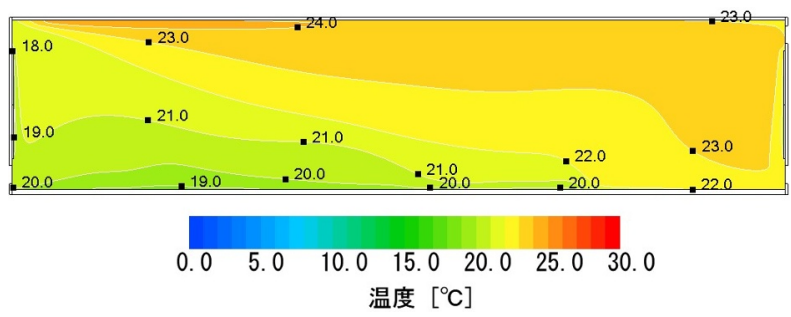

Fig. 19. The temperature distribution at 11:00 (CFD).

\section{Conclusion}

In this report, we propose a ductless air conditioning system using the Coanda effect for a medium size office buildings corresponding to the variable air volume system. In the full-scale test room, we evaluated the 
temperature environment and the air flow properties during the operation of a cooling and heating system. In addition, to validate the CFD analysis results at the time of heating pick-up, the results and measurement results were compared.

Based on this investigation, for operational cooling, it was possible to establish a good thermal environment; however, a draught was created. Based on our evaluating of the heating conditions, it was confirmed that heating of the residential area can be accomplished using floor suction. In the future, we plan to evaluate comfort performance, including a more extensive evaluation of draught.

In addition, it was shown that the accuracy of the CFD analytical results can be improved by adjusting the input conditions to the actual conditions. To obtain an accurate pick-up time by CFD, the time transition data of the outlet air volume, the supply air temperature, and the heat load are required.

\section{References}

1. Agency for Natural Resources and Energy, Ministry of Economy, Trade and Industry, Definition of ZEB and future measures proposed by the ZEB Roadmap Examination Committee (2015)

2. T. Akimoto, D. Hatori, N. Hirasuga, S. Kato, T. Ueda, Y. Sakamoto, Plan and Verification of a Midsize Office Aiming for ZEB (Part. 1) Energysaving Building Facility Technologies on a Midseze Office, Annual Meeting on The Society of Heating, Air-Conditioning and Sanitary Engineers of Japan, pp. 345-372 (2017)

3. T. Akimoto, N. Hirasuga, S. Kato, T. Ueda, Y. Sakamoto, Design and Verification of a Midsize Office Aiming for ZEB Part. 1 Energy-saving Building Facility Technologies on a Midsize Office, Summaries of Technical Papers of Annual Meeting, pp. 1215-1226 (2017)

4. ISO 7730:2005, Ergonomics of the thermal environment - Analytical determination and interpretation of thermal comfort using calculation of the PMV and PPD indices and local thermal comfort criteria, International Organization for Standardization, pp. 13 (2005)

5. ANSI/ASHRAE Standard 55-2013, Thermal Environmental Conditions for Human Occupancy, American Society of Heating, Refrigerating and AirConditioning Engineers, Inc. (2013)

6. W. Jürges, The heat transfer at a flat wall (Der Wärmeübergang an einer ebenen Wand), Beihefte zum Gesundh.-Ing. 1 (19) (1924) 